\title{
Is nighttime laparoscopic general surgery under general anesthesia safe?
}

\author{
Ahmet Kemalettin Koltka, M.D., ${ }^{1}$ Mehmet İlhan, M.D., ${ }^{2}$ Achmet Ali, M.D., ${ }^{1}$ \\ Ali Fuat Kaan Gök, M.D., ${ }^{2}$ Nükhet Sivrikoz, M.D., ${ }^{1}$ Teoman Hakan Yanar, M.D., ${ }^{2}$ \\ Mustafa Kayıhan Günay, M.D., ${ }^{2}$ Cemalettin Ertekin, M.D. ${ }^{2}$
}

${ }^{1}$ Department of Anesthesiology, İstanbul University İstanbul Faculty of Medicine, İstanbul-Turkey

${ }^{2}$ Department of General Surgery, İstanbul University İstanbul Faculty of Medicine, İstanbul-Turkey

\begin{abstract}
BACKGROUND: Fatigue and sleep deprivation can affect rational decision-making and motor skills, which can decrease medical performance and quality of patient care. The aim of the present study was to investigate the association between times of the day when laparoscopic general surgery under general anesthesia was performed and their adverse outcomes.
\end{abstract}

METHODS: All laparoscopic cholecystectomies and appendectomies performed at the emergency surgery department of a tertiary university hospital from 0I. 0I. 2016 to 12. 3I. 2016 were included. Operation times were divided into three groups: 08.0 I-I7.00 (GI: daytime), I7.0I-23.00 (G2: early after-hours), and 23.0 I-08.00 (G3: nighttime). The files of the included patients were evaluated for intraoperative and postoperative surgery and anesthesia-related complications.

RESULTS: We used multiple regression analyses of variance with the occurrence of intraoperative complications as a dependent variable and comorbidities, age, gender, body mass index (BMI), ASA score, and operation time group as independent variables. This revealed that nighttime operation $(\mathrm{p}<0.00 \mathrm{I} ; \mathrm{OR}, 6.7 ; \mathrm{Cl}, 2.6-16.9)$ and older age $(\mathrm{p}=0.004 ; \mathrm{OR}, \mathrm{I} .04 ; \mathrm{Cl}, \mathrm{I} .0 \mathrm{I}-\mathrm{I} .08)$ were the risk factor for intraoperative complications. The same analysis was performed for determining a risk factor for postoperative complications, and none of the dependent variables were found to be associated with the occurrence of postoperative complications.

CONCLUSION: Nighttime surgery and older patient age increased the risk of intraoperative complications without serious morbidity or mortality, but no association was observed between the independent variables and the occurrence of postoperative complications.

Keywords: General anesthesia; intraoperative complication; laparoscopic general surgery; operation time; postoperative complication.

\section{INTRODUCTION}

Night shifts are an inevitable part of residency and may also be unavoidable for consultant doctors in centers with high patient population. To work after normal working hours as an on-call physician leads to fatigue and sleep deprivation, which is valid both for residents and consultants. Fatigue and sleep deprivation may increase the risk of malpractices. ${ }^{[1-3]}$ There are several reports from different surgical fields reporting worse outcomes for surgeries performed during after-hours or nighttime. ${ }^{[4-7]}$ There are also reports from different coun- tries reporting that the risk of anesthesia-related incidents increase in anesthesia performed after-hours, and fatigue-related errors were reported by $86 \%$ of respondents in a nationwide survey. ${ }^{[8,9]}$ In a study using the psychomotor vigilance performance task, Gander et al. ${ }^{\left[{ }^{10]}\right.}$ found that increasing time at work was generally associated with declining performance and that this performance decline occurred only across the night shift for the fastest 10\% of responses; and, they also found that acute sleep loss increased median reaction times. However, such data are indirectly collected, and the relationship between the time of day and adverse events or patient

Cite this article as: Koltka AK, İlhan M, Ali A, Gök AFK, Sivrikoz N, Yanar TH, et al. Is nighttime laparoscopic general surgery under general anesthesia safe? Ulus Travma Acil Cerrahi Derg 2018;24:20-4

Address for correspondence: Ahmet Kemalettin Koltka, M.D.

İstanbul Üniversitesi İstanbul Tıp Fakültesi, Anesteziyoloji Anabilim Dalı, Çapa Klinikleri, 34093 Fatih, İstanbul, Turkey.

Tel: +90 212 - 4142000 E-mail: koltkak@yahoo.com

Ulus Travma Acil Cerrahi Derg 2018;24(I):20-24 DOI: 10.5505/tjtes.2017.95079 Submitted: 04.08.2017 Accepted: 04.10.2017

Copyright 2018 Turkish Association of Trauma and Emergency Surgery 
outcomes has hardly been evaluated because in modern anesthesia practice, adverse outcomes are relatively low. ${ }^{[1]}$ As an exception, Aya et al. ${ }^{[12]}$ identified a greater risk of unintended dural puncture when epidural placement was performed at nighttime than when it was performed at daytime.

Laparoscopic cholecystectomies are one of the most commonly performed surgeries in our hospital, and if the diagnosis is acute cholecystitis, it is performed as an emergent/ urgent surgery because some patients can benefit from operations performed within $24 \mathrm{~h}^{\left[{ }^{[3-15]}\right.}$ Acute appendicitis is one of the most common clinical presentations that require emergent surgery, with a lifetime incidence of approximately $8 \%{ }^{[16]}$ Laparoscopic appendectomy is a safe surgical procedure, and due to the fear of perforation, urgent/emergent surgery is accepted as a standard treatment option. ${ }^{[17,18]}$

The aim of the present study was to investigate the association between different time periods of the day (daytime, early after-hours, and nighttime) at which urgent surgery was performed and morbidity or mortality during the intraoperative and postoperative periods. We hypothesized that urgent nighttime surgery is associated with higher intraoperative and postoperative morbidity and also causes longer hospital stays and more unplanned critical care admissions.

\section{MATERIALS AND METHODS}

This retrospective study was performed at the emergency surgery department of a tertiary university hospital. After getting approval from local research ethics board (file no $2017 / 640$ ), the emergency surgery departmental records and anesthesia medical records of the patients were evaluated retrospectively. The age, gender, body mass index (BMI), comorbidities (hypertension, diabetes, ischemic heart disease, chronic obstructive pulmonary disease, obstructive sleep apnea, and chronic renal failure), American Society of Anesthesiology (ASA) score, and operation times [Group I (daytime), Group II (early after-hours), and Group III (nighttime)] were evaluated. Within the anesthesia archives, intra- and postoperative complications, such as hypotension, arrhythmias, desaturation, $\mathrm{CO} 2$ retention, and unplanned admission to intensive care unit, were found and recorded. Surgical reports expressing any intraoperative surgical complication (conversion to open surgery, bleeding, damage to vital organs, etc.) were noted. The length of hospital stay, discharge delays, postoperative complications (such as wound infection, need of gallstone extraction with ERCP, reoperation, bleeding, etc.), and readmissions to the hospital for late-term complications were evaluated and recorded. Patients with missing data were excluded from the study.

Distribution of each quantitative dataset was assessed for kurtosis and skewness, with -1.5 to +1.5 accepted as the normal distribution. Normally distributed quantitative data are presented as a meanıstandard deviation. Two normally distributed quantitative data were compared using unpaired t-tests. Qualitative data are presented as frequencies and percentages. All qualitative data were compared using chisquare test. In addition, multiple regression analyses were used to determine risk factors. All statistical analyses were performed using IBM SPSS for Windows, Version 20.0 (IBM Corp., Armonk, NY, USA), and $\mathrm{p}<0.05$ was considered to indicate statistically significant difference.

\section{RESULTS}

Data of 525 patients were screened. Three patients with missing data were excluded; thus, a total 522 patients were included in the study, $28 \mathrm{I}$ (53\%) of whom were men and $24 \mathrm{I}$ $(47 \%)$ were women. The average age and $\mathrm{BMI}$ of patients were $42.4 \pm 17.2$ years and $28.7 \pm 6.2 \mathrm{~kg} / \mathrm{m}^{2}$, respectively. Comorbidities and type of operation were listed in Table I. In total, 40 I (77\%) patients were operated by a resident surgeon, and I 2 I $(23 \%)$ were operated by a consultant surgeon. The anesthesia procedure was performed by two resident anesthesiologists in 226 (43\%) surgeries and by a consultant anesthesiologist with a resident anesthesiologist in 296 (57\%) surgeries. Intraoperative and postoperative complications had occurred in I6I (30.8\%) and 48 (9.2\%) surgeries, respectively.

Analysis of patients according to operation times revealed that 282 patients were in Group I (daytime), 78 were in Group II (early after-hours), and 162 were in Group III (nighttime). Intraoperative complications occurred more often in Group III, and consultant doctors of both surgery and anesthesia took part in Group I (Table 2). We used multiple regression analyses of variance with the occurrence of intraoperative complications as a dependent variable and comorbidities,

Table I. Patients' comorbidities and type of surgery

\begin{tabular}{lcc}
\hline Variables & $\mathbf{n}$ & $\%$ \\
\hline Diabetes mellitus & 42 & 8 \\
Ischemic heart disease & 45 & 8.6 \\
Chronic obstructive pulmonary disease & 45 & 8.6 \\
Hypertension & 12 I & 24 \\
Chronic kidney disease & 6 & I \\
Obstructive sleep apnea syndrome & 45 & 8.6 \\
Type of operation & & \\
$\quad$ Appendectomy & 268 & 51.3 \\
$\quad$ Cholecystectomy & 254 & 48.7 \\
ASA status & & \\
$\quad$ I & 275 & 53 \\
II & 158 & 30 \\
III & 86 & 16 \\
IV & 3 & I \\
\hline
\end{tabular}

ASA: American Society of Anesthesiologists classification. 
Table 2. Complication rate according to operation time

\begin{tabular}{|c|c|c|c|c|c|c|c|}
\hline & \multicolumn{2}{|c|}{$\begin{array}{l}\text { Group I } \\
(n=282)\end{array}$} & \multicolumn{2}{|c|}{$\begin{array}{c}\text { Group II } \\
(n=78)\end{array}$} & \multicolumn{2}{|c|}{$\begin{array}{l}\text { Group III } \\
(n=162)\end{array}$} & \multirow[t]{2}{*}{$\mathbf{p}$} \\
\hline & $\mathbf{n}$ & $\%$ & $\mathbf{n}$ & $\%$ & $\mathbf{n}$ & $\%$ & \\
\hline Consultant surgeon attending & 98 & 34 & 12 & 15 & 11 & 7 & $<0.00 I^{*}$ \\
\hline Consultant anesthesist attending & 235 & 83 & 24 & 31 & 37 & 23 & $<0.001^{*}$ \\
\hline Intraoperative complication & 54 & 20 & 29 & 37 & 77 & 48 & $<0.001^{*}$ \\
\hline Postoperative complication & 17 & 6 & 11 & 14 & 20 & 12 & 0.055 \\
\hline Readmission to hospital & 7 & 3 & 4 & 5 & 8 & 5 & 0.500 \\
\hline Mortality rate & None & & None & & None & & 1.000 \\
\hline
\end{tabular}

age, gender, BMI, ASA score, and operation time group as independent variables. This revealed that Group III $(\mathrm{p}<0.00 \mathrm{I}$; OR, 6.7; $\mathrm{Cl}, 2.6-16.9)$ and older age $(p=0.004$; OR, I.04; $\mathrm{Cl}$, I.0I-I.08) were among the risk factors for intraoperative complications (Table 3 ). In addition, we performed analysis

Table 3. Intraoperative complications

\begin{tabular}{lcc}
\hline Variables & $\mathbf{n}$ & $\%$ \\
\hline Transient hypotension & 151 & 28.9 \\
Tachycardia & 5 & 0.95 \\
Arrhythmia & 2 & 0.4 \\
Bradycardia & $\mathrm{I}$ & 0.2 \\
Hypertension & $\mathrm{I}$ & 0.2 \\
Hypoxia & $\mathrm{I}$ & 0.2 \\
Conversion to open surgery & $\mathrm{I}$ & 0.2 \\
Total & $\mathrm{I} 62$ & \\
\hline
\end{tabular}

Two patients experienced more than one complication.

Table 4. Postoperative complications

\begin{tabular}{lcc}
\hline Variables & $\mathbf{n}$ & $\%$ \\
\hline Infection/abscess & 17 & 3.26 \\
Pancreatitis & 6 & 1.15 \\
ERCP requirement & 6 & 1.15 \\
Reoperation & 6 & 1.15 \\
Minor bleeding & 4 & 0.77 \\
Rehospitalization due to abdominal pain & 3 & 0.59 \\
Brid ileus & 3 & 0.59 \\
Bilioma & I & 0.2 \\
Pneumonia & I & 0.2 \\
Upper respiratory tract infection & I & 0.2 \\
Total & 48 & \\
\hline
\end{tabular}

ERCP: Endoscopic retrograde cholangiopancreatography. for determining a risk factor for postoperative complications and found that none of the dependent variables were associated with the occurrence of postoperative complications (Table 4).

\section{DISCUSSION}

The main finding of the present study is that performing nighttime surgery increased the risk of intraoperative complications. In addition, older age was found to be a significant risk factor for intraoperative complications.

When we reassessed the present data, we found that most of the intraoperative complications were due to anesthesia mismanagement and nighttime surgery was a risk factor for intraoperative complications. Little data is available on this topic. However, several manuscripts have reported that anesthesia residents are chronically sleepy and $32 \%$ of them can recall a fatigue-related clinical error in the last 6 months of their practice. ${ }^{[10,19]}$ In an audit performed in a university hospital, the authors reported that the risk of incidents increased in anesthesia performed after-hours and stated that the most common cardiovascular incident is hypotension due to several etiologies and the incidents most commonly occurs during the induction and maintenance phases. ${ }^{\left[{ }^{8]}\right.}$ The combination of ASA I and ASA 2 patients covered up $78 \%$ of the patient population in that study, which is quite similar to the ASA scores of the patients in the present study $(83 \%$ were ASA I or 2 ). The results of this audit support our findings.

Fortunately, most if not all intraoperative complications led to minor effects or no adverse outcome in our patients because none of them had required unplanned intensive care admission or had experienced serious perioperative adverse events, such as myocardial infarction or acute renal failure. The possible reasons of this may be several. First, in our department, the vast majority anesthesia procedures are performed by a team of two doctors (one staff anesthesiologist or a senior resident with a junior resident). We have implemented anesthesia safety checklists focusing on moni- 
toring application, allergies, anesthesia preparation, etc. All residents are trained to manage critical situations, such as difficult mask ventilation or intubation, and a manual crisis booklet is attached to all anesthesia machines. A study performed by Arbous et al. ${ }^{[20]}$ confirmed that the presence of two anesthetists instead of one decreases the risk of complications during emergent anesthesia, which is consistent with the findings of the present study. As we did not focus on the reasons of complications, we can only speculate about them. We believe some of them may be due to judgment errors and faulty techniques, which may be easily attributed to fatigue and sleep deprivation. In a simulation study of rested versus sleep-deprived anesthesiologists, Howard et al. ${ }^{[2]}$ found that subjects' performance on clinically relevant tasks and probes during simulated cases showed modest impairment when sleep-deprived and that individuals in both states made clinically relevant errors with a trend toward more errors when sleep-deprived. In their audit, Saito et al. ${ }^{[8]}$ stated that inappropriate speeds of drug injection are one of the reasons for errors in critical events, and these results indirectly support our speculations. ${ }^{[8,21]}$ In addition, Arbous et al. ${ }^{[20]}$ found that compared with indirect availability, direct availability of the anesthesiologist during maintenance was associated with a significantly lower risk; in the present study, direct availability of the staff anesthesiologist was less during nighttime surgery, and this may be one of the reasons for increased risk of intraoperative complications.

The most frequent postoperative complications in the study were infection/abscess (3.26\%), pancreatitis (1.15\%), ERCP requirement (I.I5\%), and reoperation (I.I5\%). In a study focusing on a similar patient population, Yaghoubian et al. ${ }^{[22]}$ found abscess rate of $2.5 \%$ in the daytime appendectomy group, which is quite similar to the combined data of the present study. Although Yaghoubian et al. found the abscess rate in nighttime appendectomy group to be $1.5 \%$, the patients in the present study were older and had higher rates of comorbidity (for example, the rate of diabetes was $8 \%$ in the present study vs $4 \%$ and $3.2 \%$ in the daytime and nighttime appendectomy groups, respectively), which may explain the difference. Yaghoubian et al. ${ }^{[22]}$ found that nighttime surgery was not a risk factor for surgical complications, which is consistent with the results of the present study.

The reoperation rate was $1.15 \%$ in the present study. In a series of 1607 patients, Guevara et al. ${ }^{[23]}$ found a reoperation incidence of $5.9 \%$, which is higher than that in our study. Although elective cholecystectomy, emergency cholecystectomy, and appendectomy were among the most common surgeries performed, other operations, such as colon, rectum, and gastric resections and elective and emergency hernia repairs were included in their study, and the mean age was 61 years, which is greater than that in our study. Therefore, all these differences together may easily explain their higher reoperation rates.

This study has several limitations. First, it was a retrospective study using the data of a single center. We could not determine whether the surgery start times of some high-risk patients were postponed to daytime by surgeons or anesthesiologists in order to increase patient safety or to lower the risk of complications. Although we could identify readmissions of patients due to postoperative complications, we could not ensure whether all patients with postoperative complications had been admitted to our hospital. The amount of sleep loss is an important factor, and there are several descriptions of sleep deprivation. ${ }^{[24,25]}$ However, in the present study, we did not evaluate the complication rates and sleep deprivation. The anesthesia team and/or surgical team could be sleep-deprived, and this might change the complication rates.

In summary, nighttime surgery increased the risk of intraoperative complications without serious morbidity or mortality after laparoscopic cholecystectomy and appendectomy under general anesthesia. With increasing age, the risk for intraoperative complications was found to increase directly. No correlation was observed between nighttime surgery and postoperative complications.

\section{Conflict of interest: None declared.}

\section{REFERENCES}

1. Chan MY Cohen H, Spiegel BM. Fewer polyps detected by colonoscopy as the day progresses at a Veteran's Administration teaching hospital. Clin Gastroenterol Hepatol 2009;7:1217-23. [CrossRef]

2. Wu AW, Folkman S, McPhee SJ, Lo B. Do house officers learn from their mistakes? Qual Saf Health Care 2003;12:221-6. [CrossRef]

3. Sturm L, Dawson D, Vaughan R, Hewett P, Hill AG, Graham JC, et al. Effects of fatigue on surgeon performance and surgical outcomes: a systematic review. ANZ J Surg 2011;81:502-9. [CrossRef]

4. Ricci WM, Gallagher B, Brandt A, Schwappach J, Tucker M, Leighton R. Is after-hours orthopaedic surgery associated with adverse outcomes? A prospective comparative study. J Bone Joint Surg Am 2009;91:2067-72.

5. Wu JX, Nguyen AT, de Virgilio C, Plurad DS, Kaji AH, Nguyen V, et al. Can it wait until morning? A comparison of nighttime versus daytime cholecystectomy for acute cholecystitis. Am J Surg 2014;208:911-8.

6. Russell P. Night Time Surgery 'Doubles Death Risk'. Medscape 2015. Available at: https://www.medscape.com/viewarticle/868160. Accessed Nov 20, 2017.

7. Romanowski A. How Risky Is Having Surgery at Night? Medscape 2016. Available at: https://www.medscape.com/viewarticle/869248. Accessed Nov 20, 2017.

8. Saito T, Wong ZW, Thinn KK, Poon KH, Liu E. Review of critical incidents in a university department of anaesthesia. Anaesth Intensive Care 2015;43:238-43.

9. Gander PH, Merry A, Millar MM, Weller J. Hours of work and fatiguerelated error: a survey of New Zealand anaesthetists. Anaesth Intensive Care 2000;28:178-83.

10. Gander P, Millar M, Webster C, Merry A. Sleep loss and performance of anaesthesia trainees and specialists. Chronobiol Int 2008;25:1077-91.

11. Gaba DM. Human error in dynamic medical domains. In: Bogner MS, editor. Human error in medicine. Hillsdale, NJ: Lawrence Erlbaum Associates; 1994. p. 197-224. 
12. Aya AG, Mangin R, Robert C, Ferrer JM, Eledjam JJ. Increased risk of unintentional dural puncture in night-time obstetric epidural anesthesia. Can J Anaesth 1999;46:665-9. [CrossRef]

13. Gelbard R, Karamanos E, Teixeira PG, Beale E, Talving P, Inaba K, et al. Effect of delaying same-admission cholecystectomy on outcomes in patients with diabetes. Br J Surg 2014;101:74-8. [CrossRef]

14. Goh JC, Tan JK, Lim JW, Shridhar IG, Madhavan K, Kow AW. Laparoscopic cholecystectomy for acute cholecystitis: an analysis of early versus delayed cholecystectomy and predictive factors for conversion. Minerva Chir 2017;72:455-3.

15. Jarrar MS, Chouchène I, Fadhl H, Ghrissi R, Elghali A, Ferhi F, et al. Early versus delayed laparoscopic cholecystectomy for lithiasic acute cholecystitis during emergency admissions. Results of a monocentric experience and review of the literature. Tunis Med 2016;94:519-24.

16. Addiss DG, Shaffer N, Fowler BS, Tauxe RV. The epidemiology of appendicitis and appendectomy in the United States. Am J Epidemiol 1990;132:910-25. [CrossRef]

17. Yang J, Yu K, Li W, Si X, Zhang J, Wu W, et al. Laparoscopic Appendectomy for Complicated Acute Appendicitis in the Elderly: A Single-center Experience. Surg Laparosc Endosc Percutan Tech 2017;27:366-8.

18. Litz CN, Stone L, Alessi R, Walford NE, Danielson PD, Chandler NM. Impact of outpatient management following appendectomy for acute ap- pendicitis: An ACS NSQIP-P analysis. J Pediatr Surg 2017. pii: S00223468(17)30406-2.

19. Howard SK, Gaba DM, Rosekind MR, Zarcone VP. The risks and implications of excessive daytime sleepiness in resident physicians. Acad Med 2002;77:1019-25. [CrossRef]

20. Arbous MS, Meursing AE, van Kleef JW, de Lange JJ, Spoormans HH, Touw P, et al. Impact of anesthesia management characteristics on severe morbidity and mortality. Anesthesiology 2005;102:257-68. [CrossRef]

21. Howard SK, Gaba DM, Smith BE, Weinger MB, Herndon C, Keshavacharya $S$, et al. Simulation study of rested versus sleep-deprived anesthesiologists. Anesthesiology 2003;98:1345-55. [CrossRef]

22. Yaghoubian A, Kaji AH, Ishaque B, Park J, Rosing DK, Lee S, et al. Acute care surgery performed by sleep deprived residents: are outcomes affected? J Surg Res 2010;163:192-6. [CrossRef]

23. Guevara OA, Rubio-Romero JA, Ruiz-Parra AI. Unplanned reoperations: is emergency surgery a risk factor? A cohort study.J Surg Res 2013;182:11-6. [CrossRef]

24. Jensen A, Milner R, Fisher C, Gaughan J, Rolandelli R, Grewal H. Shortterm sleep deficits do not adversely affect acquisition of laparoscopic skills in a laboratory setting. Surg Endosc 2004;18:948-53. [CrossRef]

25. Veasey S, Rosen R, Barzansky B, Rosen I, Owens J. Sleep loss and fatigue in residency training: a reappraisal. JAMA 2002;288:1116-24. [CrossRef]

\section{ORIJINAL ÇALIŞMA - ÖZET}

\section{Gece genel anestezi altında yapılan laparoskopik genel cerrahi olguları güvenli mi?}

\section{Dr. Ahmet Kemalettin Koltka, ${ }^{1}$ Dr. Mehmet İlhan, ${ }^{2}$ Dr. Achmet Ali, ${ }^{1}$ Dr. Ali Fuat Kaan Gök, ${ }^{2}$ Dr. Nükhet Sivrikoz, ${ }^{1}$} Dr. Teoman Hakan Yanar, ${ }^{2}$ Dr. Mustafa Kayıhan Günay, ${ }^{2}$ Dr. Cemalettin Ertekin ${ }^{2}$

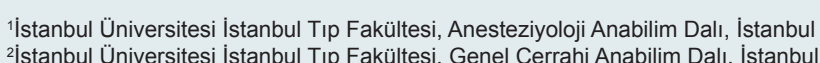

AMAÇ: Yorgunluk ve uykusuzluk doğru karar verme yetisini ve motor becerileri etkileyerek tıbbi performansı ve hasta bakım kalitesini düşürebilir. Bu çalışmanın amacı, farklı zamanlarda genel anestezi altında yapılan laparoskopik genel cerrahi olguları ile istenmeyen sonuçlar arasında ilişki olup olmadığını araştırmaktır.

GEREÇ VE YÖNTEM: Üçüncü düzey bir üniversite hastanesinin acil servisinde 0I.0I.20I6-3I. I2.20 I6 tarihleri arasında ameliyat edilen tüm laparoskopik kolesistektomi ve apendektomi olguları çalışmaya dahil edildi. Ameliyat zamanları üçe ayrıldı: 08.0 I-I7.00 arası (GI: gündüz), I7.0I-23.00 arası (G2: erken mesai sonrası) ve 23.0I-08.00 arası (G3: gece). Çalışmaya dahil edilen hastaların dosyaları taranarak ameliyatta ve ameliyat sonrası dönemlerde anestezi veya cerrahiye ait komplikasyon yaşayıp yaşamadıkları incelendi.

BULGULAR: Bağımsız değişkenler olan yandaş hastalıklar, yaş, cinsiyet, vücut kitle indeksi, ASA skoru ve ameliyat zamanı ile bağımlı değişken olan ameliyat sırasında komplikasyon sıklığı arasındaki ilişki multipl regresyon analizi yapılarak değerlendirildi. Gece yapılan ameliyatlar ( $p<0.00$ I OR: 6.7 $\mathrm{Cl}$ [2.6-16.9]) ve yüksek yaşın ( $p=0.004 \mathrm{OR}$ : I.04 Cl [I.0I-I.08]) ameliyat sırasında komplikasyon sıklığı için risk faktörü olduğu saptandı. Aynı değerlendirme ameliyat sonrası komplikasyonlar için yapıldığında yukarıdaki bağımsız değişkenler ile ameliyat sonrası komplikasyon sıklığı arasında ilişki olmadığı saptandı.

TARTIŞMA: Gece yapılan ameliyatlarda ve yaşlı hastalarda ameliyat sırasında komplikasyon riski ciddi morbidite veya mortalite artışına neden olmadan artmaktayken ameliyat sonrası komplikasyon sıklığında artışa neden olan bir bağımsız değişken bulunmamıştır.

Anahtar sözcükler: Ameliyat zamanı; ameliyat sırasında komplikasyon; ameliyat sonrası komplikasyon; genel anestezi; laparoskopik cerrahi.

Ulus Travma Acil Cerrahi Derg 2018;24(I):20-24 doi: 10.5505/tjtes.2017.95079 